\title{
Effects of lead and zinc on the proximate composition of post juvenile clarias gariepinus
}

\author{
Bawa- Allah Kafilat. Adebola, Saliu Joseph. Kayode* \\ Department of Zoology, University of Lagos, Lagos, Nigeria \\ Email address: \\ debbiebawy@yahoo.co.uk(Bawa- Allah Kafilat. Adebola), saliujk@yahoo.com(Saliu Joseph. Kayode)
}

To cite this article:

Bawa- Allah Kafilat. Adebola, Saliu Joseph. Kayode. Effects of Lead and Zinc on The Proximate Composition of Post Juvenile Clarias Gariepinus, International Journal of Nutrition and Food Sciences. Vol. 2, No. 2, 2013, pp. 8-14. doi: 10.11648/j.ijnfs.20130202.12

\begin{abstract}
Effects of sub lethal concentrations of lead and zinc salts $\left(\mathrm{Pb}\left(\mathrm{NO}_{3}\right)_{2}\right.$ and $\left.\mathrm{ZnCl}_{2}\right)$ on the proximate composition and energy content of the flesh of post juvenile Clarias gariepinus was investigated in this study. All proximate components (amino acids, protein, and lipid) and total energy content, except carbohydrate showed a consistent reduction in detected levels as compared to values recorded at day 0 in exposed fishes and their controls. Physiological response of organisms was also indicated to be affected by other environmental stressors during the experiment apart from the investigated metal salts.
\end{abstract}

Keywords: Proximate Composition; Lead; Zinc; Clarias Gariepinus

\section{Introduction}

Proximate parameters and total energy content are useful as bio indicators of stress from environmental pollution. Besides direct damage from pollutants, there is the energy cost of detoxification mechanisms. Resources (carbohydrate, protein, lipid and other energy giving components) invested in detoxification reduce extent of damage and possible death, however at a cost to health and production rate of organisms. Reference [1] reported a decrease in protein and carbohydrate levels of Calta calta a fresh water fish exposed to mercury chloride and attributed this to mobilization of the components to produce energy needed for detoxification. However, only limited studies have been carried out to evaluate effect of heavy metals on health and nutritional value of fishes, and also the use of proximate parameters as biomarkers of environmental pollution, hence more research is justifiable along these lines.

Fish accounts for about one fifth of world total supply of animal protein and this has risen five folds over the last forty years from 20 million metric tons to 98 million metric tons in 1993 and projected to exceed 150 million metric tons by the year 2010 [2]. Fish farming activity in Nigeria started about 50 years ago and today it is recognized as one of the most important aspects of Nigeria's agricultural sector [3].

The African catfish (sharp tooth catfish) Clarias gariepinus has a pan African distribution ranging from the Nile to
West Africa and from Algeria to South Africa. It is commonly cultured in fish farms in Nigeria and of great economic interest, it is also the most common fresh water fish widely consumed in Nigeria [4].

This study aims to determine the effect of sub lethal concentrations of zinc and lead on the proximate composition and energy output of post juvenile $C$. gariepinus.

\section{Materials and Method}

\subsection{Test Animals; Source and Acclimatization}

C.gariepinus post juveniles (6-8 weeks old) were purchased from local fish farms in Surulere Lagos and transported in polythene bags half filled with pond water to holding tanks (length: $45.00 \mathrm{~cm}$, height: $34.00 \mathrm{~cm}$, bottom diameter: $25.00 \mathrm{~cm}$ and top diameter: $35.00 \mathrm{~cm}$ ) in the laboratory.

The post juveniles were kept in the plastic holding tanks containing dechlorinated water, to acclimatize to laboratory conditions ( $28 \pm 2^{\circ} \mathrm{c}$, R.H $70 \pm 2 \%$ ) for a period of seven days before they were used in the bioassays. The post juveniles were fed with fish food (Coppens,) at 3\% of body weight twice daily, and the water was changed once every 48hours, aerating it continuously with Bzagdon air pump (double type 1200).

\subsection{Test Compounds}


Zinc as $\mathrm{ZnCl}_{2} \cdot 4 \mathrm{H}_{2} \mathrm{O}$ analar grade (molecular weight $136.28 \mathrm{~g}$, purity $98 \%$ ) and lead as $\mathrm{Pb}\left(\mathrm{NO}_{3}\right)_{2}$ (molecular weight $331.21 \mathrm{~g}$, purity $99.5 \%$ ), manufactured by J.T. Baker, a division of Mallinekrodt Baker Inc.

\subsection{General Bioassay Techniques}

\subsubsection{Bioassay Containers}

Circular plastic bowls (volume: 6 liters, bottom diameter: $22 \mathrm{~cm}$ and top diameter: $33 \mathrm{~cm}$ ) were used as bioassay container.

\subsubsection{Preparation of Test Media}

Stock solutions were prepared by taking computed amount of test compounds which were made up to a desired volume of distilled water, to achieve solutions of desired strength. This was mixed together using a glass rod to ensure proper mixing. To prepare test media for bioassays, computed volume of stock solutions were pipette out and made up to 5 liters to achieve predetermined concentration of test media (actual concentration of zinc and lead in each solution of known strength was computed based on molecular weight of test compound).

Test media were always made up to 5 liters for post juveniles because preliminary studies showed that 5 post juveniles survived well in 5 liters of media for 7 days without aeration.

\subsubsection{Selection of Animal for Bioassay}

Active post juveniles of similar age and size (6-8 weeks old, mean snout to tail length: $15.00-22.00 \mathrm{~cm}$, mean weight: $31.00-55.00 \mathrm{~g}$ ) were taken from holding tanks and randomly assigned to containers involved in any one series of experiment.

\subsection{Bioassays}

\subsubsection{Proximate Studies of Clarias Gariepinus Exposed to Sub Lethal Concentrations of (Zn and Pb) Acting Singly in Semi Static Bioassays}

8 active post juveniles of similar age and size were exposed to sub lethal concentration and control experiments in 2 replicates (4 post juveniles per replicate). These series of bioassays went on for 28 days and the semi static bioassay procedure was adopted. This is to avoid drastic changes in concentration of test media via evaporation and excessive reduction in dissolved oxygen level. In the semi static procedure, each test media was changed into a fresh solution of exactly the same concentration of heavy metal salt or untreated control respectively once every four days, transferring the same exposed test animals into the freshly prepared test media over the 28 day period of the experiment.

At time intervals of 7, 14 and 28 days, one live $C$. gariepinus per replicate, ( two per treatment and two from untreated control) were randomly selected, dissected and flesh removed and kept refrigerated pending further analysis.

C. gariepinus were exposed to sublethal concentrations of test heavy metals in separate experiments as follows:

$\mathrm{ZnCl}_{2} \cdot 4 \mathrm{H}_{2} \mathrm{O}$ was tested at:

$0.01 \mathrm{mMol} / 1\left(0.1\right.$ of $\left.96 \mathrm{hrLC}_{50}\right)$

$0.001 \mathrm{mMol}^{1}\left(0.01\right.$ of $\left.96 \mathrm{hrLC}_{50}\right)$

$0.0001 \mathrm{mMol} / 1\left(0.001\right.$ of $\left.96 \mathrm{hrLC}_{50}\right)$

b. $\mathrm{Pb}\left(\mathrm{NO}_{3}\right)_{2}$ was tested at:

$0.02 \mathrm{mMol} / 1\left(0.1\right.$ of $\left.96 \mathrm{hrLC}_{50}\right)$

$0.002 \mathrm{mMol} / 1\left(0.01\right.$ of $\left.96 \mathrm{hrLC}_{50}\right)$

$0.0002 \mathrm{mMol} / 1\left(0.001\right.$ of $\left.96 \mathrm{hrLC}_{50}\right)$

\subsubsection{Proximate and Energy Content Analysis of Flesh of Clarias Gariepinus Exposed to Sublethal Concen- trations of $\mathrm{Zncl}_{2}$ and $\mathrm{Pb}\left(\mathrm{NO}_{3}\right)_{2}$}

Total amino acids, protein, carbohydrate, fat (lipid) and energy content of fishes exposed to the heavy metals were analyzed using the following methods.

\subsubsection{Total Amino Acids}

Determination with ninhydrin

When amino acids are reacted with ninhydrin hydrate, at $\mathrm{pH} 5$ and $100^{\circ} \mathrm{C}$ for a standard period of time, a purple blue compound, the ammonium salt of diketohydrindylidenediketohydrindamine is produced as the major product. Ninhydrin will also yield a similar purple blue product with ammonia and primary amines. The absorbance of the purple blue product is measured at 570nm. Proline and hydroxyproline give a yellow product that is partly transformed into enolbetaine by the loss of water. Extensive heating of proline and ninhydrin in acetic acid at $100^{\circ} \mathrm{C}$ will give a purple blue product when enolbetaine condenses with another molecule of ninhydrin hydrate to give a final purple blue product. There is no difference in the colours of the purple blue products for different amino acids when the amino acids are reacted in solution as described above.

Procedure

The analysis is performed by the addition of $0.2 \mathrm{ml}$ of ninhydrin reagent $(2 \mathrm{mg}$ of ninhydrin in $20 \mathrm{mM}$ acetic acidacetate buffer, $\mathrm{pH} 5)$ to $1.0 \mathrm{ml}$ of the amino acid solution. The solution is heated for $10 \mathrm{~min}$ at $100^{\circ} \mathrm{C}$ and cooled, and the absorbance is measured at $570 \mathrm{~nm}$ for all amino acids except proline, which is measured at 440nm. A standard curve is prepared for the different amino acids. The limit of sensitivity is $0.1 \mu \mathrm{mol}$.

\subsubsection{Total Protein Content}

This was determined using the Biuret method [5]. 5.0ml of blank Biuret reagent prepared by dissolving $\mathrm{CuSO}_{4}$ $5 \mathrm{H}_{2} \mathrm{O}$ crystal in $500 \mathrm{ml}$ of distilled water was added to sample blank. These were mixed well and allowed to stand for 20 minutes at room temperature $25-27^{\circ} \mathrm{C}$. Absorbance was read for one test and standard against a blank at $540 \mathrm{~nm}$. The concentration of protein was calculated using: optical density for standard $\times$ concentration of standard.

\subsubsection{Total Lipid Content}

\section{Lipid extraction}

Lipids contain both polar and non polar groups in their molecule; hence they are better extracted from tissues using 
a mixture of polar and non polar solvents. Such a mixture is provided by mixing chloroform and methanol in their right proportions.

Procedure

$1 \mathrm{~g}$ of sample tissue was weighed and homogenized with $20 \mathrm{ml}$ of choloform-methanol mixture $(2: 1 \mathrm{v} / \mathrm{v})$ for $5 \mathrm{mi}$ nutes. The homogenate was poured into a conical flask and then corked and allowed to stand for 10 minutes. Homogenate was filtered into a separating funnel using the sintered glass funnel. The debris was re-extracted with $5 \mathrm{ml}$ of the extraction solvent (chloroform-methanol) and then filtered. $5 \mathrm{ml}$ of $0.1 \% \mathrm{NaCl}$ solution was added to the filtrate and shaken thoroughly to partition into aqueous and organic phases. The organic phase contains extracted lipids. The mixture was allowed to stand for 3 minutes and the lower organic phase was collected. The aqueous phase was reextracted by shaking with $5 \mathrm{ml}$ of chloroform and the organic layers were pooled into beakers. The beakers were placed in hot water bath at $40^{\circ} \mathrm{C}$ and evaporated to dryness. The extracted lipid in the beaker was dissolved with $10 \mathrm{ml}$ of cholorform.

Estimation of Total Lipid

$0.5 \mathrm{ml}$ each of extracted lipid in chloroform, working lipid standard and distilled water was transferred into three different test tubes. $5 \mathrm{ml}$ of concentrated $\mathrm{H}_{2} \mathrm{SO}_{4}$ was added to each test tube and mixed thoroughly, and then heated in a boiling water bath for 10 minutes. Test tubes were allowed to cool to room temperature and $2 \mathrm{ml}$ of the contents of each test tube were transferred to clean cuvettes. $3 \mathrm{ml}$ of phosphoric acid-vanillin reagent was added to each cuvette and shaken thoroughly, and allowed to stand for 10 minutes. Absorbance of the extract and lipid standard was read at $520 \mathrm{~nm}$.

Calculation

$\mathrm{Mg}$ total lipids $=\underline{\mathrm{A}}_{\underline{\underline{u}}} \times \mathrm{C}_{\mathrm{s}}=\underline{240 \mathrm{~A}_{\mathrm{u}}}$

$\mathrm{A}_{\mathrm{s}} \quad \mathrm{A}_{\mathrm{s}}$

$\mathrm{A}_{\mathrm{u}}=$ absorbance of unknown

$\mathrm{A}_{\mathrm{s}}=$ absorbance of standard

$\mathrm{C}_{\mathrm{s}}=$ concentration standard $=240 \mathrm{mg} / 100 \mathrm{mg}$

\subsubsection{Total Carbohydrate}

The principle is based on the use of perchloric acid to digest the food sample [6] and the hydrolised starches and other soluble sugars released are determined spectrophotometrically at $630 \mathrm{~nm}$, and expressed as percentage glucose. The antherone [7] method was employed with some modifications.

Extraction of Carbohydrate

$1 \mathrm{~g}$ of sample tissue was weighed and transferred into a $100 \mathrm{ml}$ graduated and stoppered measuring cylinder containing $10 \mathrm{ml}$ water. The sample was stirred with a long glass rod. $10 \mathrm{ml}$ of $52 \%$ cold perchloric acid was added and stirred for 30 minutes, the contents was diluted to $100 \mathrm{ml}$ with distilled water, mixed and filtered into a $250 \mathrm{ml}$ graduated flask. The content was again diluted to the ml mark and mixed thoroughly to obtain sample extract.

Estimation of Total Carbohydrate
$45 \mathrm{ml}$ of the sample extract was diluted to $450 \mathrm{ml}$ with distilled water. $1 \mathrm{ml}$ of the diluted filtrate was pipetted into three test tubes. $1 \mathrm{ml}$ of water was pipetted into two test tubes and $1 \mathrm{ml}$ of glucose into two test tubes respectively. $5 \mathrm{ml}$ of freshly prepared $0.10 \%$ antherone reagent was pipetted into each of the test tubes and corked; the test tubes were gently shaken to mix contents. The test tubes were labeled and placed in a water bath $\left(37^{\circ} \mathrm{C}\right)$ for 12 minutes, and then allowed to cool to room temperature. The absorbance of the samples and standard was read at $630 \mathrm{~nm}$ against the reagent blanks.

Calculation

$\%$ glucose $=\underline{25 \mathrm{~A}_{1}} \times 100$

$\mathrm{xA}_{2}$

$\mathrm{X}=$ weight of sample

$\mathrm{A}_{1}=$ absorbance of diluted sample

$\mathrm{A}_{2}=$ absorbance of diluted standard

\subsubsection{Total Energy Content}

The energy content was estimated by the use of Atwater factors of 4,9 , and 4 for its crude protein, crude fat and total carbohydrate as main energy sources as reported by [8] and [9]. The values of crude protein, crude fat, and total carbohydrate were multiplied by 4, 9 and 4 respectively, and summing up the products and expressing the result as $\mathrm{kcal} / 100 \mathrm{~g}$ sample.

\subsection{Statistics}

One-way analysis of variance (ANOVA) was used to compare the means of results obtained from proximate analysis, and where a significant difference $(p<0.05)$ was obtained, Duncan test was used to detect the source of the difference.

Means of parameters obtained during the period of the experiment for each treated group and control were compared, and those obtained on each sampling day for treated groups and control was also compared.

\section{Results}

\subsection{Proximate and Energy Content Analysis of Flesh of Clarias Gariepinus Exposed to Sub Lethal Concen- trations of $\mathrm{Pb}\left(\mathrm{NO}_{3}\right)_{2}$ and $\mathrm{Zncl}_{2}$}

The general trend observed after analysis of results was a significant reduction in most of the proximate parameters and energy content from day 0 , in test organisms exposed to sub lethal concentrations of $\mathrm{Pb}\left(\mathrm{NO}_{3}\right)_{2}$ and $\mathrm{ZnCl}_{2}$ and controls respectively.

\subsubsection{Total Amino Acids}

Total amino acids content reduced significantly $(\mathrm{p}<0.05)$ after 7 days in fishes exposed to $\mathrm{Pb}\left(\mathrm{NO}_{3}\right)_{2}$, however there was no variation in total amino acids after the initial reduction $(\mathrm{p}<0.05)$ from day 0 in groups exposed to $\mathrm{ZnCl}_{2}$ and the control. Comparison of total amino acids content of groups exposed to sublethal concentrations of $\mathrm{Pb}\left(\mathrm{NO}_{3}\right)_{2}$ 
and that exposed to $\mathrm{ZnCl}_{2}$, showed marked variation only at 7 days where higher values were recorded in those

groups exposed to $\mathrm{Pb}\left(\mathrm{NO}_{3}\right)_{2}$ (Fig. 1).

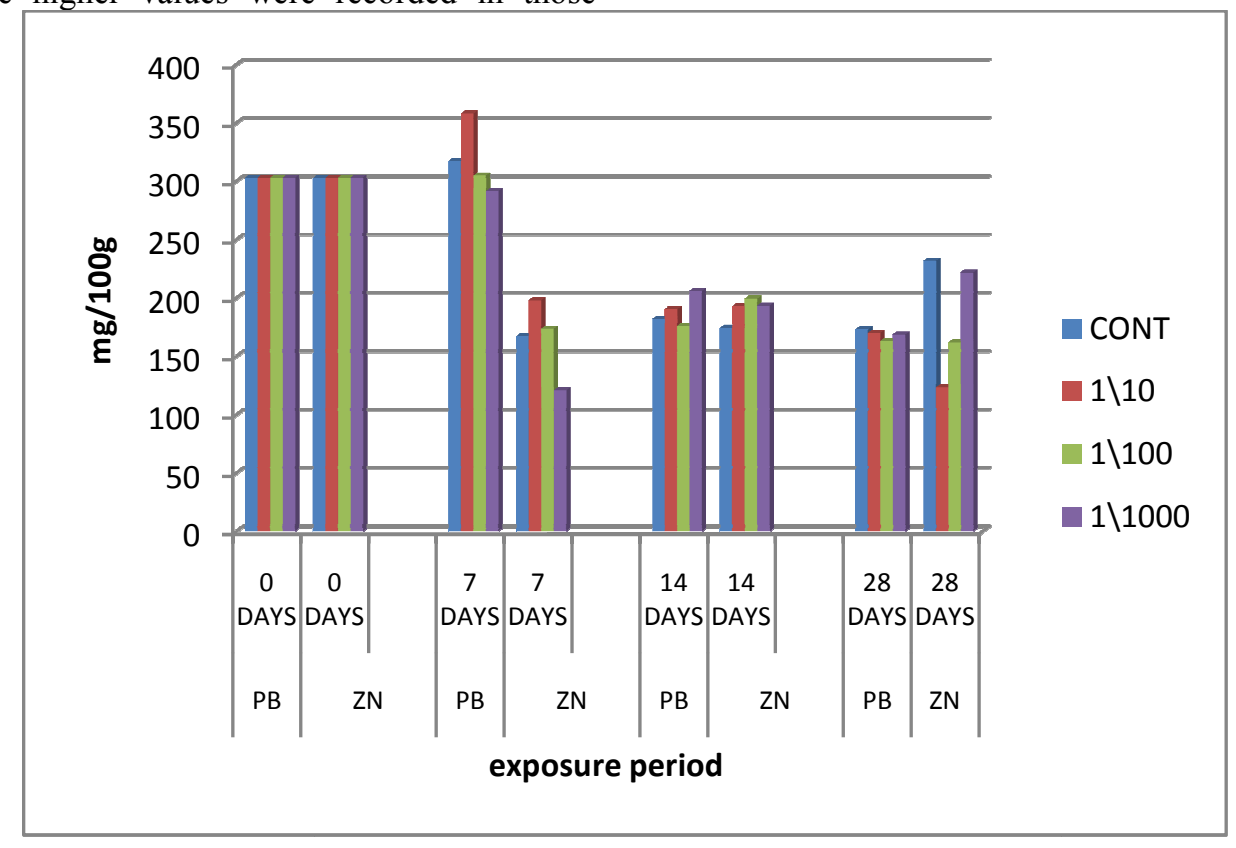

Figure 1. Total Amino Acid (mg/100g) in groups of Clarias gariepinus exposed to $\left.\left.\mathrm{Pb}_{(\mathrm{NO}}\right)_{2}\right)_{2}$ and $\mathrm{ZnCl}_{2}$

\subsubsection{Protein}

Protein followed the general trend, with higher values $(\mathrm{p}<0.05)$ recorded at day 0 as compared to other days during the experiment in groups exposed to concentrations of $\mathrm{Pb}\left(\mathrm{NO}_{3}\right)_{2}$ and the control.

For test organisms exposed to $\mathrm{ZnCl}_{2}$, protein levels were also higher $(\mathrm{p}<0.05)$ at day 0 for exposed groups and control.

Comparison of protein values in the various groups exposed to sublethal concentrations of $\mathrm{Pb}\left(\mathrm{NO}_{3}\right)_{2}$ and $\mathrm{ZnCl}_{2}$ respectively did not show marked variations of protein levels on all sampling days during the experiment (Fig. 2).

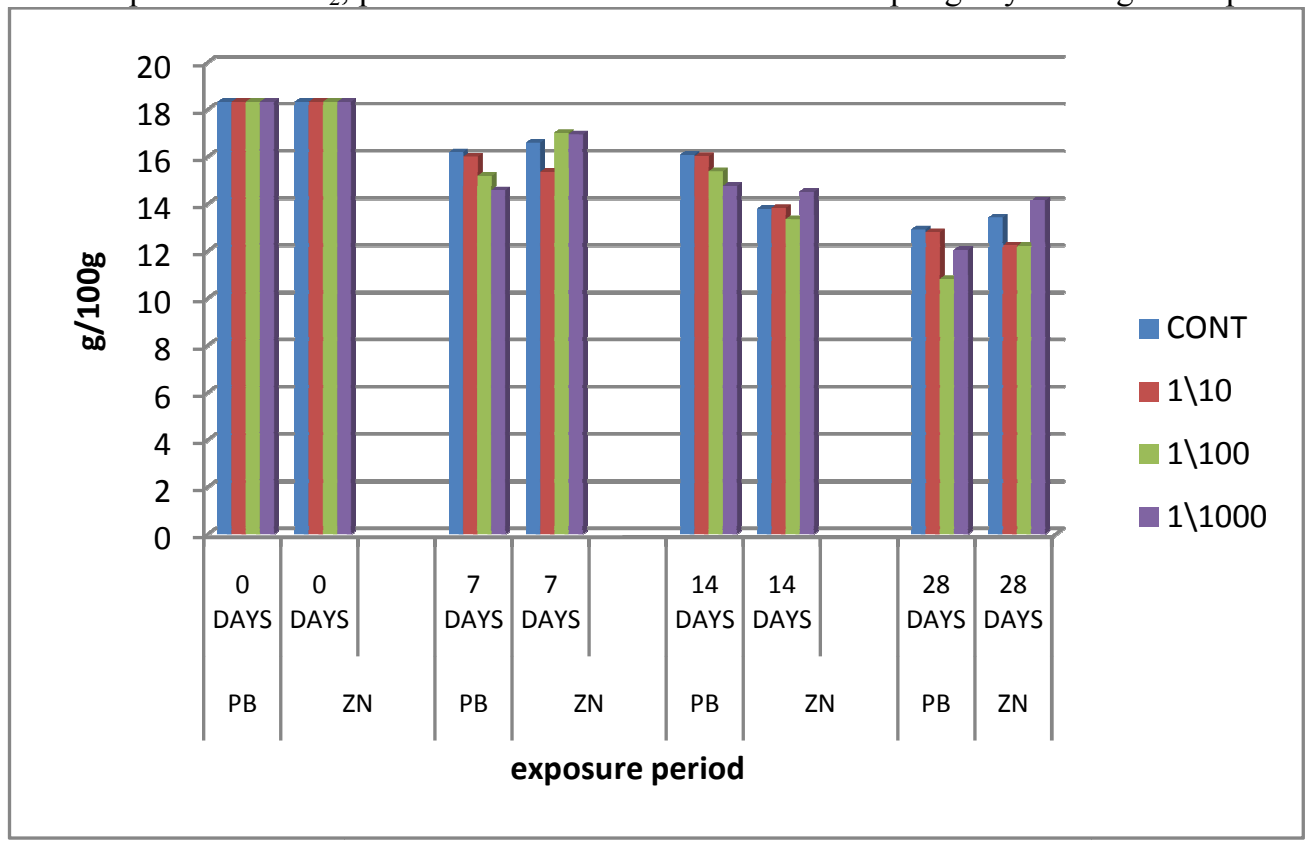

Figure 2. Protein Content (g/100g) in groups of Clarias gariepinus exposed to $\mathrm{Pb}\left(\mathrm{NO}_{3}\right)_{2}$ and $\mathrm{ZnCl}_{2}$.

\subsubsection{Carbohydrate}

Carbohydrate content did not vary significantly $(\mathrm{p}<0.05)$ from that recorded on day 0 and also during the experiment in groups exposed to concentrations of $\mathrm{Pb}\left(\mathrm{NO}_{3}\right)_{2}$ and the control.
In test organisms exposed to concentrations of $\mathrm{ZnCl}_{2}$ and the control, carbohydrate content did not vary $(\mathrm{p}<0.05)$ from that recorded on day 0 and also during the experiment.

Comparison of carbohydrate content in test organisms exposed to the different heavy metals did not show any 
marked variation on each sampling day during the experi- ment (Fig. 3).

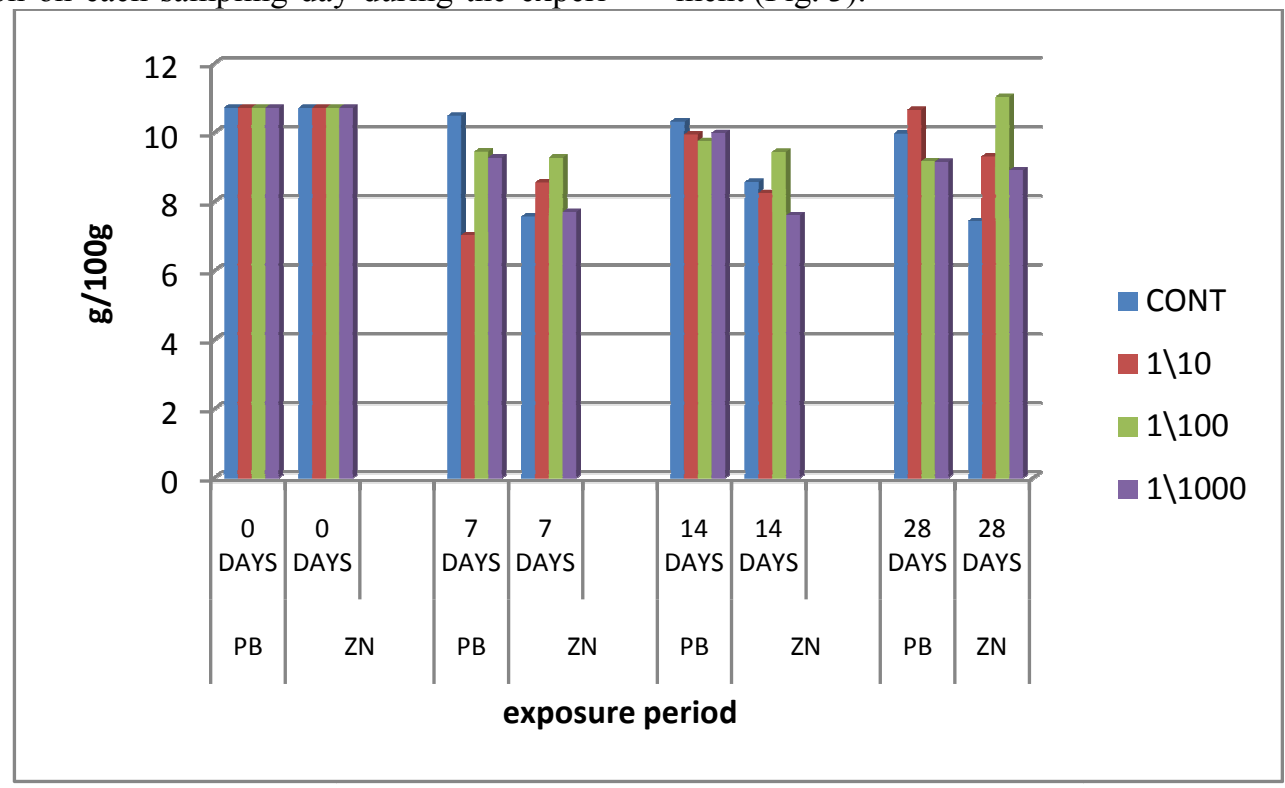

Figure 3. Carbohydrate content $(\mathrm{g} / 100 \mathrm{~g})$ in groups of Clarias gariepinus exposed to $\mathrm{Pb}\left(\mathrm{NO}_{3}\right)_{2}$ and $\mathrm{ZnCl} l_{2}$

\subsubsection{Lipid}

Lipid content was highest $(\mathrm{p}<0.05)$ at day 0 as compared to other sampling days during the period of the experiment in groups exposed to concentrations of $\mathrm{Pb}\left(\mathrm{NO}_{3}\right)_{2}$ and the control.

For test organisms exposed to concentrations of $\mathrm{ZnCl}_{2}$ and the control, higher lipid values $(\mathrm{p}<0.05)$ was recorded at day 0 .
There was also no significant difference $(\mathrm{p}<0.05)$ in lipid levels when control and exposed groups were compared on all sampling days.

There were no marked differences in lipid contents of the test organisms exposed to sublethal concentrations of the two heavy metals respectively during the course of the experiments (Fig. 4).

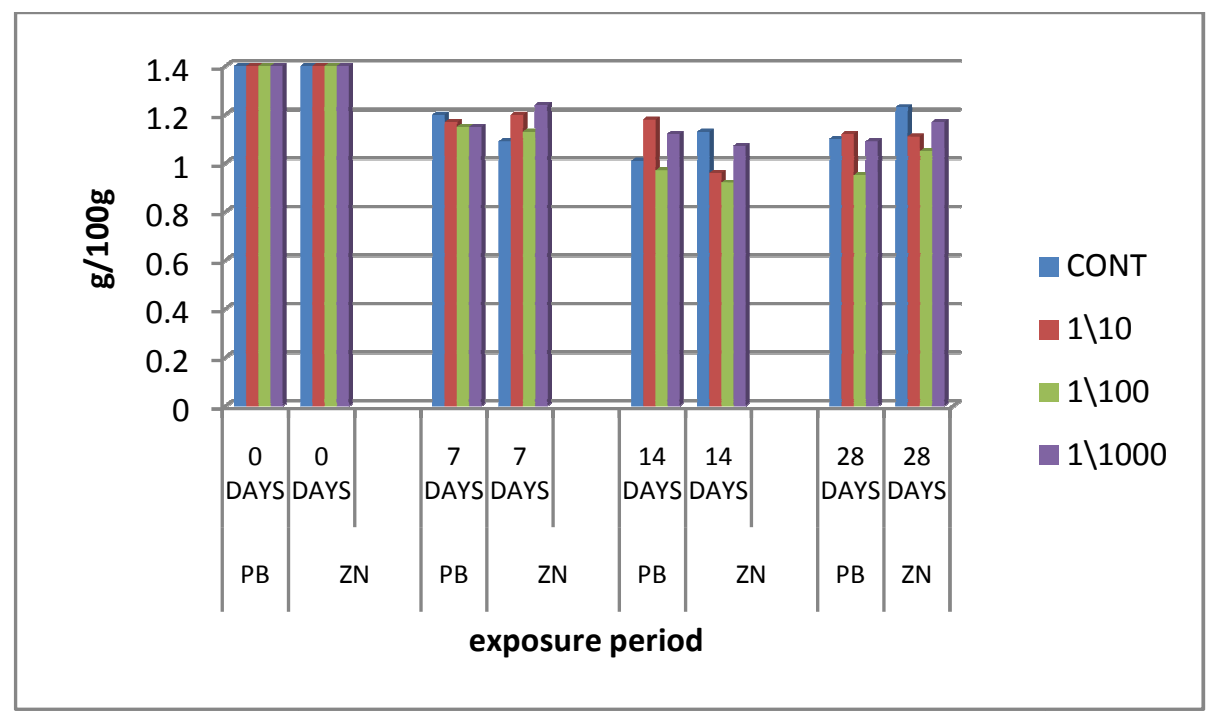

Figure 4. Lipid content (g/100g) in groups of Clarias gariepinus exposed to $\mathrm{Pb}\left(\mathrm{NO}_{3}\right)_{2}$ and $\mathrm{ZnCl}_{2}$.

\subsubsection{Energy Content}

Energy content was higher $(\mathrm{p}<0.05)$ at day 0 when compared to other sampling days during the experiment in test organisms exposed to concentration of $\mathrm{Pb}\left(\mathrm{NO}_{3}\right)_{2}$ and the control.

A significant difference $(\mathrm{p}<0.05)$ was recorded at 7 days when energy content $(\mathrm{kcal} / 100 \mathrm{~g})$ in exposed groups were compared to control during the experiment, control had the highest energy content (117.54 \pm 2.1355$)$ as compared to $102.69 \pm 4.9215,108.89 \pm 1.3930$ and $105.79 \pm 2.9981$ in exposed groups.

For test organisms exposed to concentrations of $\mathrm{ZnCl}_{2}$ and the control, higher values $(\mathrm{p}<0.05)$ of energy content was also recorded at day 0 as compared to other sampling days.

There were no significant variations $(\mathrm{p}<0.05)$ in energy 
content when exposed groups were compared to control on each sampling day.

No marked variation was observed in the energy content of the test organisms exposed to the sublethal concentra- tions of the two heavy metals in the separate experiments on the sampling days during the course of the experiments (Fig. 5).

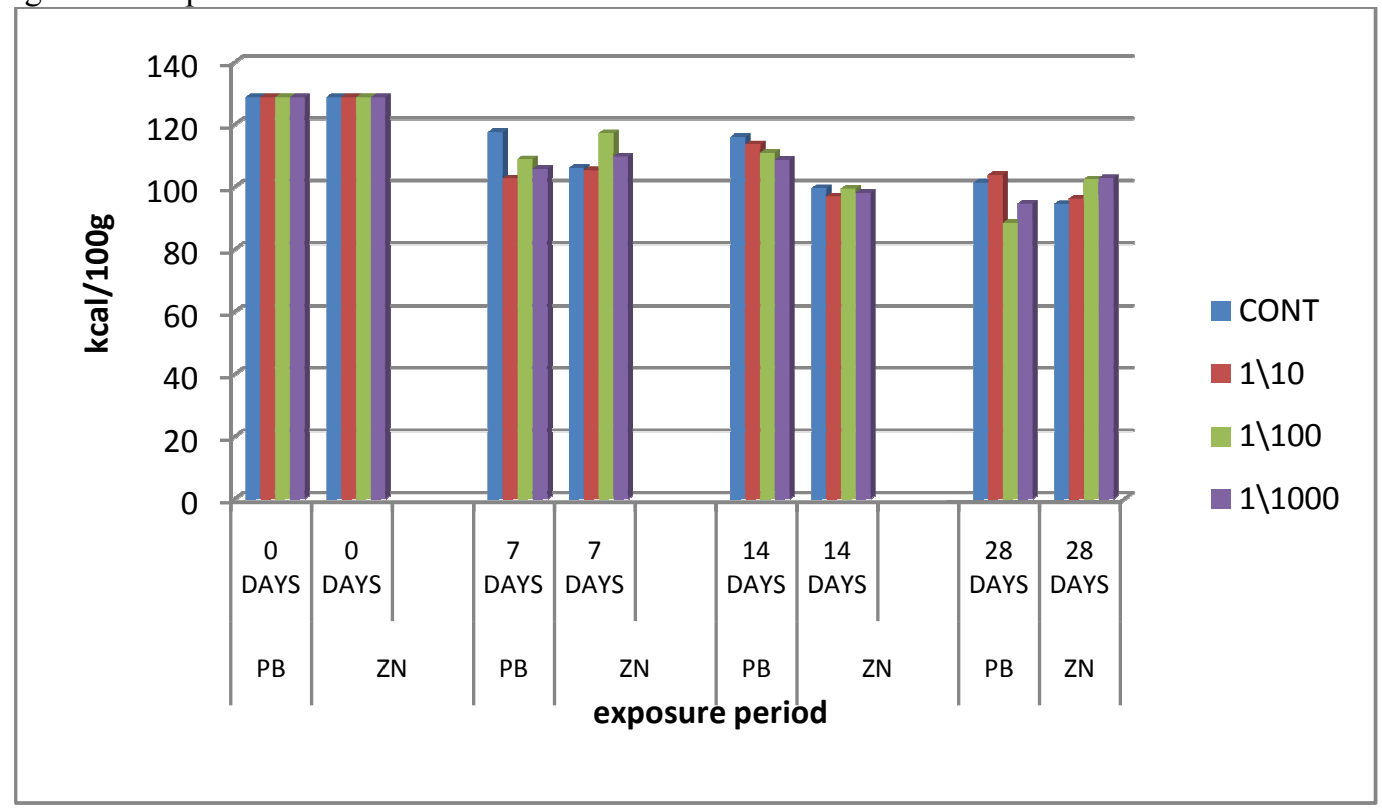

Figure 5. Energy Content (kcal/100g) in groups of Clarias gariepinus exposed to $\mathrm{Pb}\left(\mathrm{NO}_{3}\right)_{2}$ and $\mathrm{ZnCl}_{2}$.

\section{Discussion and Conclusion}

Proximate parameters (protein, carbohydrate, lipids) are basic components of metabolic activities that have to do with supply of energy that is used to drive the major physiological processes in the body. Organisms compensate for effects of stressors on its physiology, but only at a price. Besides direct damage, there is the energetic cost of detoxification mechanisms, in which case the resources that the organisms invests in detoxification reduces its chances of death but at a cost in terms of reduction in health and loss of production [10].

Fishes are a rich source of protein to humans; however exposure to environmental stressors may have adverse effects on the health, nutritional value and in the long term, production of the fish species.

Results from this study showed that most proximate parameters (amino acids, protein and lipid) and energy content decreased concurrently with increase in exposure period in the two groups of organisms exposed to concentrations of $\mathrm{Pb}\left(\mathrm{NO}_{3}\right)_{2}$ and $\mathrm{ZnCl}_{2}$ and the controls respectively. Protein and amino acids however showed reduced levels in organisms exposed to concentrations of $\mathrm{Pb}\left(\mathrm{NO}_{3}\right)_{2}$ and $\mathrm{ZnCl}_{2}$ when compared to their controls at day 28 respectively. Reduction in proximate composition and energy content in fishes exposed to heavy metals is in agreement with the work of [11] who studied the Effect of Water Pollution on Four Bioindicators of Aquatic Resources in Sindh Pakistan. They reported a decrease in lipids, proteins and amino acids of fishes collected from water bodies polluted with heavy metals and attributed this to the degradation of the products and use of the degraded products for metabolic activities.

Very few works has been done, especially in Nigeria to evaluate the effect of heavy metals on health and nutritional values of fishes and the possible use of proximate composition and total energy content as biomarkers of environmental pollution. Results from this study have shown that environmental stressors can have adverse effects on proximate composition and energy levels, hence, more research is justifiable to evaluate the effect of heavy metals on health and nutritional value of fishes and where possible, laboratory data should be related to field observations where other environmental factors apart from heavy metals are at play in order to arrive at reliable conclusions. More research will also help to establish the usefulness of proximate parameters and energy content as biomarkers of environmental pollution.

Heavy metals are just one group of pollutants that threatens the stability of aquatic ecosystems worldwide and sustainable use of water resources. Fish farming is serving as an effective buffer to wild edible fish species in many countries of the world including Nigeria. However, it is time to stop the scourge of environmental pollution, before surface and ground waters become too polluted to support cultivable fish species.

\section{References}

[1] Prasath, D. P. and Arivoli, S. (2008). Biochemical Study of Freshwater Fish Catla catla with Reference to Mercury Chloride. Iranian Journal of Environmental Health, Science 
and Engineering. 5(2): 109-116.

[2] F.A.O. (1991). Fish for Food and Employment. Food and Agricultural Organization, Rome.

[3] Longhurst, A.R. (1961). Report on the Fisheries. Ministry Economic Development, Lagos.

[4] Olaifa, F.E., Olaifa, A.K., Adelaja, A.A., and Owolabi, A.G. (2004). Heavy Metal Contamination of Clarias gariepinus From a Lake and Fish Farm in Ibadan Nigeria. African Journal of Biomedical Research. 7:145-148.

[5] Gonall, A.G., Bardawill, C.J. and David, M.M. (1949). Determination of Total Protein. Journal of Biological Chemistry. 177: 751-760.

[6] AOAC. 1984. Official Methods of Analysis. 14th Edition, Association of Official Analytical Chemists. Washington DC.

[7] Clegg, K.M. (1956). Total Available Carbohydrate in Foods. Journal of Science Food and Agriculture. 7: 40-44.

[8] Edem, D.O., Amugo,C.I. and Eka, O.U. (1990). Chemical
Composition of Yam Beans (Sphenostylis stenocarpa). Tropical science. 30: 59-63.

[9] Onyeike, E.N., Olungwe, T. and Uwakwe, A.A. (1995). Effect of Heat Treatement and Defatting on the Proximate Composition of Some Nigerian Local Soup Thickners. Food Chemistry. 53: 173-175.

[10] Walker, C.H., Hopkin, S.P., Silby, R.M. and Peakall, D.B. (2001). Principles of Ecotoxicology. Taylor and Francis group, New York. 308pp.

[11] Amzat, R., Aziz, F., and Yousfi, M. (2008). Effects of Water Pollution on Four Bioindicators of Water Resources in Sindh Pakistan. Research Journal Of Environmental Sciences.2 (6): 465-473.

[12] Mason, C.F. (1992). Biology of Freshwater Pollution. 2nd Edition Longman. 351pp.

[13] Oyewo, Z. O. (1998). Industrial Sources and Distribution of Heavy Metal in Lagos Lagoon And Their Biological Effects On Estuaries Animals. Ph.D. Thesis, University Of Lagos. 274pp. 